\title{
Light environment under Rhododendron maximum thickets and estimated carbon gain of regenerating forest tree seedlings
}

\author{
T. T. Lei ${ }^{1, *}$, E. T. Nilsen ${ }^{2}$ and S. W. Semones ${ }^{3}$ \\ ${ }^{1}$ Department of Environmental Solution Technology, Ryukoku University, 1-5 Yokoba, Seta-Oe, Otsu, 520- \\ 2194, Japan; ${ }^{2}$ Department of Biological Sciences, Virginia Tech, Blacksburg, VA, 24061, USA; ${ }^{3}$ Novozymes \\ Biologicals Inc., 5400 Corporate Circle, Salem, VA, 24153, USA; *Author for correspondence (e-mail: \\ tomlei@rins.ryukoku.ac.jp; phone: +81-77-544-7110; fax: +81-77-544-7130)
}

Received 18 December 2004; accepted in revised form 21 September 2005

Key words: Appalachian, Light response, Photosynthesis, PPFD, Site factors, Sunflecks

\begin{abstract}
.
Canopy tree recruitment is inhibited by evergreen shrubs in many forests. In the southern Appalachian mountains of the USA, thickets of Rhododendron maximum L. restrict dominant canopy tree seedling survival and persistence. Using $R$. maximum as a model system, we examined available light under the thickets and the photosynthetic responses of seedlings of canopy tree species. We tested the hypothesis that the additional shading from under $R$. maximum drives carbon gain in seedlings below the threshold for growth and survival. A reduction in light under the thicket was found where canopy openness (derived from canopy photographs) under $R$. maximum was half the amount measured in forest without $R$. maximum. R. maximum also reduced direct radiation by $50 \%$ and diffuse radiation by $12-29 \%$ compared to forest without the shrub layer. Mean mid-day PPFD (photosynthetically active photon flux density between 1000 and $1400 \mathrm{~h}$ ) under $R$. maximum (obtained from quantum sensors) was below $10 \mu \mathrm{mol} \mathrm{m}^{-2} \mathrm{~s}^{-1}$ on both clear and overcast days and the amount of sunflecks greater than $10 \mu \mathrm{mol} \mathrm{m}^{-2} \mathrm{~s}^{-1}$ PPFD was only $0-$ 20 min per day. In contrast, forest without $R$. maximum received a mean PPFD of $18-25 \mu \mathrm{mol} \mathrm{m}^{-2} \mathrm{~s}^{-1}$ on clear days and a cumulative sunfleck duration of 100-220 min per day in all sky conditions. Consistent with light availability between the sites, daily carbon gain in Quercus rubra L. seedlings was lower in forest with $R$. maximum compared to forest where the shrub was absent. The presence of the shrub layer also significantly suppressed average mid-day photosynthesis of both $Q$. rubra and Prunus serotina Ehrt. seedlings on 8 out of 11 measurement dates. However, parameters derived from light response curves between seedlings growing in forest sites with or without a thicket of $R$. maximum was significantly different only in $A_{\max }$ (maximum photosynthetic rate), indicating a lack of further acclimation to the deeper shade under $R$. maximum. While the additional shade cast by $R$. maximum is sufficient to prevent the regeneration of tree seedlings under this shrub, there was sufficient heterogeneity in light under the thicket to imply that deep shade only partially explains the complete inhibition of regenerating canopy trees under $R$. maximum.
\end{abstract}

\section{Introduction}

Variations in understorey spatial and temporal liaht environment ate main determinante of carbon gain and survival of regenerating forest seedlings and saplings (Canham et al. 1994; Lei et al. 2002). Spatially, the light environment is high heterngeneoss with a declining gradert 
from the canopy to the forest floor. Temporally, light in the forest understorey exhibits a dynamic daily pattern of persistent shade and occasional sunflecks (e.g., Chazdon and Fetcher 1984; Chazdon 1988) and a seasonal pattern associated with the turnover of canopy foliage. Even in a mixed boreal forest, light transmission can increase from $5.9 \%$ during the summer to $22-59 \%$ in spring and autumn (Constabel and Lieffers 1996).

The presence of subcanopy plants, such as the evergreen shrub Rhododendron maximum $\mathrm{L}$. ( $R$. maximum), can impose a further reduction in light availability for regenerating tree seedlings. $R$. maximum is a dominant understorey shrub in the forest of the southern Appalachian mountains of eastern United States. The additional shading created by $R$. maximum could reduce available light to levels below the light compensation point for photosynthesis (LCP), lead to seedling mortality and disrupted forest regeneration. Similar effects on forest regeneration have been observed in other evergreen understorey layers such as Kalmia latifolia in eastern U.S.A. (Monk and Day1985), Rhododendron ponticum in Europe (Cross 1981), and Quercus myrsinaefolia (Takenaka 1986) and Sasa bamboo in Japan (Lei and Koike 1998). Shading by $R$. maximum on tree seedling survival could serve as a model system in understanding the processes regulating forest regeneration in areas where a dominant subcanopy shrub layer presides.

The influence of low light intensity on photosynthetic capacity of canopy tree seedlings has been investigated for species from ecosystems such as northern hardwood (Ellsworth and Reich 1992), tropical (Chazdon and Field 1987), Virginia piedmont (Groninger et al. 1996), European deciduous (Johnson et al. 1997), and coastal plain forests (Jones and Mcleod 1990). All of these studies conclude that among all environmental factors measured, photosynthetic capacity of understorey canopy tree seedlings is most highly dependent upon light intensity. However, these and other studies have not investigated the effects of the very low PPFD caused by a subcanopy shrub layer on the photosynthetic capacity of young tree seedlings.

To assess carbon gain of regenerating seedlings, it is necessary to first determine the heterogeneous light environment in the forest understorey (Fladeland et al. 2003). Quantum sensors and hemispherical photographs allow comparisons of daily light patterns in multiple sites and dates (Rich 1990; Mitchell and Whitmore 1993; Jennings et al. 1999). Light factors derived from hemispherical photographs are correlated with seedling and sapling growth in the tropical (e.g., Turner 1990; Clark et al. 1993; Oberbauer et al. 1993; Whitmore et al. 1993), temperate and boreal (e.g., Easter and Spies 1994; Constabel and Lieffers 1996) forests. And in some cases, differences in height and diameter growth of plants among sites were associated with light factors derived from hemispherical photographs (i.e., direct, diffuse or total; Anderson 1964; Clark et al. 1993). There is generally a good correspondence between light parameters estimated from hemispherical photographs and direct measurements taken with quantum sensors (Chazdon and Field 1987; Rich et al. 1993; Easter and Spies 1994; Roxburgh and Kelly 1995, but see Machado and Reich 1999).

Within the prevailing understorey light environment, seedling regeneration depends on a net positive carbon gain over the growing season. Shade adapted leaves of temperate woody species require $2-15 \mu \mathrm{mol} \mathrm{m}^{-2} \mathrm{~s}^{-1}$ PPFD to achieve LCP (Larcher 1995). Therefore, the energetic balance and survival of regenerating tree seedlings depends heavily on the spatial and temporal distribution of PPFD reaching below the $R$. maximum shrubs and on the LCP of those regenerating seedlings. Although other factors such as allelopathy (Nilsen et al. 1999), mycorrhizal association (Walker et al. 1999) and below ground resources (Nilsen et al. 2001; Beier et al. 2005) may contribute to seedling mortality under $R$. maximum, we hypothesize that light limitation is having an overriding effect. To test this hypothesis we made detailed measurements of spatial and temporal light patterns using both hemispherical photographs and quantum sensors in forest sites with and without thickets of $R$. maximum. To relate the available light level to carbon gain, we made in situ gas exchange measurements in seedlings of several common tree species. An estimation of seasonal carbon gain based on photosynthetic response patterns of the seedlings allowed us to test whether light availability was an overriding factor limiting canopy tree regeneration under this evergreen shrub compared with forest sites without an understorey of the evergreen shrub. 


\section{Methods and materials}

\section{Site description}

This study was conducted at Coweeta Hydrologic Laboratory, a 2185 ha US Forest Service experimental station. Coweeta Hydrologic Laboratory is a member site of the Long Term Ecological Research (LTER) network, located in the Nantahala Mountains of the Blue Ridge Mountain physiographic province near Otto, North Carolina $\left(35^{\circ} 02^{\prime} \mathrm{N}, 83^{\circ} 24^{\prime} \mathrm{W}\right.$; Swank and Crossley 1988). Vegetation has been described as northern hardwood, cove hardwood, oak, and oak-pine communities (Day et al. 1988). The site was situated on a north facing slope at an elevation of $1000 \mathrm{~m}$ (asl) dominated by a northern red oak forest with patchy thickets of $R$. maximum in the understorey. Thickets are known to occur more widely in cove forests and on north-facing slopes (Monk and Day 1985; Lipscomb and Nilsen 1990; Dobbs 1995). The canopy of $R$. maximum was $3-4 \mathrm{~m}$ and the forest canopy $12-15 \mathrm{~m}$. The regional climate is classified as marine, humid with cool summers, mild winters, and adequate rainfall during all seasons (Swank and Crossley 1988).

\section{Experimental design}

Six localities with the same NE aspect and $26^{\circ}$ slope were randomly selected and one plot (approximately $25 \mathrm{~m} \times 25 \mathrm{~m}$ ) was established in each locality. Three of the plots were within the thickets of $R$. maximum and three plots were in forest without $R$. maximum. In each plot, fifteen $2 \times 2 \mathrm{~m}$ experimental subplots were placed in a regular design with a $2 \mathrm{~m}$ buffer around each plot.

To assess the effect of $R$. maximum on the microclimate of the forest floor, PPFD was assessed using quantum sensors and canopy photographs. Quantum sensors (Li-Cor model 190s, Lincoln, Nebraska, USA) were installed at fixed locations $20 \mathrm{~cm}$ above ground at two of the six main sampling blocks (one sensor in each forest type). Quantum sensors recorded PAR at $1 \mathrm{~min}$ intervals, and stored the minimum, maximum, and mean at 10 -min intervals in a datalogger (Campbell Scientific, Inc., model $21 \mathrm{X}$ microdatalogger, Logan, Utah, USA). This time interval was chosen to canture the cocurrence of sunfecks /Chazden and Fetcher 1984) while allowing extended recording periods. Shorter than 1 min sunflecks can be a significant portion of the total number of daily sunflecks but may not necessarily change the total daily PPFD received by understorey plants (e.g., Chazdon 1988). The spatial variability in light level in the forest understorey was assessed using an array of 8 equally spaced gallium arsenide photo-diodes within a $7.2 \mathrm{~m}$ diameter circle (Hamamatsu Co., Bridgewater, NJ, USA) positioned $50 \mathrm{~cm}$ above ground. The photo-diodes (calibrated to a LI-190s quantum sensor) showed close correspondence with quantum sensor readings (data not shown) indicating that the light levels recorded by the quantum sensors were representative of the general light condition at the two locations.

Hemispherical canopy photographs were also used to evaluate the spatial and temporal variation in light environment. In 1996, images were taken repeatedly at the center of each of the 90 plots. Images were recorded using a Nikon $8 \mathrm{~mm}$ fisheye lens attached to a Nikon FM2 camera and Kodak Tri-X film at +1 and +2 stops above the light meter setting to increase the contrast. The top of the lens was $0.78 \mathrm{~m}$ from the forest floor. The lens was leveled and aligned with magnetic north. Exposures were made on overcast days or during morning and evening hours when the sun was obscured by the landscape. Images were developed using Kodak Microdol-X developer and scanned with a Polaroid SprintScan 35 Film Scanner to convert images to BMP graphical files. The BMP images were analyzed for standard direct and diffuse site factors using a software program developed by M. Ishizuka (FEW 4.0; personal communication). We used the same setting for transmissivity (0.65) for all images (Gates 1980). Errors introduced by the hemispherical photographs, particularly at very low site factor values (Rich 1990), had been minimized by using photographs taken on overcast days and by maintaining a consistent contrast and sky/foliage pixel separation for all images during the analysis. Clark et al. (1993) estimated that the error in their process was $\pm 0.5 \%$ of the proportion of the total radiation under a plant canopy relative to an open sky (Rich 1989).

Photosynthetic rates of 2-yr-old Quercus rubra L. (Fagaceae) and Prunus serotina Ehrhart. (Rosaceae) sedlings wer measured in sitw using a 
portable gas exchange system with an attached LED light source (LiCor 6400, LiCor, Inc., Lincoln, Nebraska, USA). Seedlings of these two dominant overstory tree species were established in the experimental plots by planting seeds collected from nearby parent trees. These species were selected to represent an intermediate (Quercus rubra) and an intolerant (Prunus serotina) species. LCP was derived from light response curves where leaves were first allowed to reach photosynthetic steady state at $1200 \mu \mathrm{mol} \mathrm{m}^{-2} \mathrm{~s}^{-1}$ PPFD, photosynthesis was then measured by reducing light intensity in a step-wise fashion until darkness. Between 6 and 10 plants of each species in each forest type were measured. By applying the best fit quadratic function to each response curve (using Sigma Stat, SPSS Inc, Chicago, IL, USA), the light compensation point was determined.

\section{Results}

\section{Light environment}

Quantum sensor data revealed that while sunflecks were scarce under either canopy cover, they were more frequent and brighter in forest sites without a thicket of $R$. maximum (abbreviated as $\mathrm{F}$ henceforth) compared to sites where $R$. maximum was present (abbreviated as $\mathrm{F}+\mathrm{R}$ henceforth). We defined "sunflecks" as pulses of light above $10 \mu \mathrm{mol} \mathrm{m}^{-2} \mathrm{~s}^{-1}$ PPFD following that used by Chazdon (1988) where weak direct radiation is distinguished from shade light. The site differences in light dynamics were apparent across the entire growing season (Figure 1). In early spring, for about a month before canopy closure, light conditions under both canopy types were favorable for carbon assimilation by oak seedlings whose leaves show positive photosynthesis beginning in late April (data not shown). After canopy closure in late May, the duration of sunflecks in the 10$300 \mu \mathrm{mol} \mathrm{m}^{-2} \mathrm{~s}^{-1}$ PPFD in $\mathrm{F}+\mathrm{R}$ sites was less than 50 min per day and about $4 \mathrm{~h}$ per day in $\mathrm{F}$ sites. Higher intensity sunflecks were virtually absent after canopy closure in both forest types (Figure 1). Since sunflecks were measured using ten 1 -min averages over a $10 \mathrm{~min}$ period, we were not able to differentiate between intervals consisting of several shorter sunflecks and those with a continuous sunfleck
We also found, based on quantum sensor data, that during the growing season the mean daily PPFD reaching the forest floor in $F+R$ sites was only $12-20 \%$ of that in F sites on either overcast or clear days (Table 1). Similarly, the percentage of total PPFD received that was above $10 \mu \mathrm{mol} \mathrm{m}^{-2} \mathrm{~s}^{-1}$ in $\mathrm{F}+\mathrm{R}$ sites was $19 \%$ less than that found in $F$ sites. Maximum PPFD in $F+R$ sites was $20-35 \%$ of that in $F$ sites on overcast days, and was much lower on clear days (Table 1).

Comparisons of the light environment using canopy photographs taken at the 90 plots showed a similar pattern to those derived from quantum sensors, i.e., the amount of direct sunlight reaching the forest floor was generally greater in $F$ sites than in F+R sites (Figure 2). In July, the range of canopy openness at all sites was $0.8-2.4 \%$. Without the canopy foliage (in December), canopy openness increased by $20-30$ fold (to $25 \%$ ) in $\mathrm{F}$ sites and by 10 fold $(<20 \%)$ in $F+R$ sites. In May when the forest canopy was still relatively open, the amount of direct radiation passing through canopy gaps overlapped substantially between $F\left(0-101.4 \mathrm{~mol} \mathrm{~m}^{-2}\right.$ month $\left.^{-1}\right)$ and $F+R$ sites $\left(0-73.3 \mathrm{~mol} \mathrm{~m}^{-2}\right.$ month $\left.^{-1}\right)$. The same measurements taken in July after canopy closure was $1-58.8 \mathrm{~mol} \mathrm{~m}^{-2}$ month $^{-1}$ for $\mathrm{F}$ sites and 0.4-37.4 mol m month $^{-1}$ for $F+R$ sites. The calculated percentage of light penetration (i.e., the percentage of full sun reaching the forest floor) in July was $0.89-1.93 \%$ in $F$ sites and $0.87-1.53 \%$ in $\mathrm{F}+\mathrm{R}$ sites (Table 2). The amount of diffuse light reaching the forest floor is proportional to canopy openness and is calculated using the standard overcast sky (SOC) algorithm (Anderson 1964). Although there was significant among site variation in the light level, SOC for F+R sites was $71 \%$ (in May) and $88 \%$ (in July) that of F sites. Similar to the direct light factor, there was also a broad overlap in diffuse light factor between $F+R$ and $F$ sites where, in May they were $1.6-8.0 \%$ and $1.2-$ $9.4 \%$, respectively, and in July they were $1.4-3.9 \%$ and $1.2-4.5 \%$, respectively.

Light level was highly heterogeneous even within the same forest cover. While it was generally brighter in $F$ sites, some $F$ sites (e.g., $5_{F}$ ) were shadier than some $F+R$ sites (e.g., $3_{F+R}$, Table 2). This may be related to high densities of understorey tree saplings in $5_{\mathrm{F}}$ which intercepted

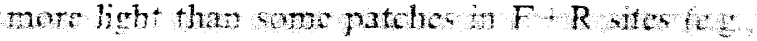




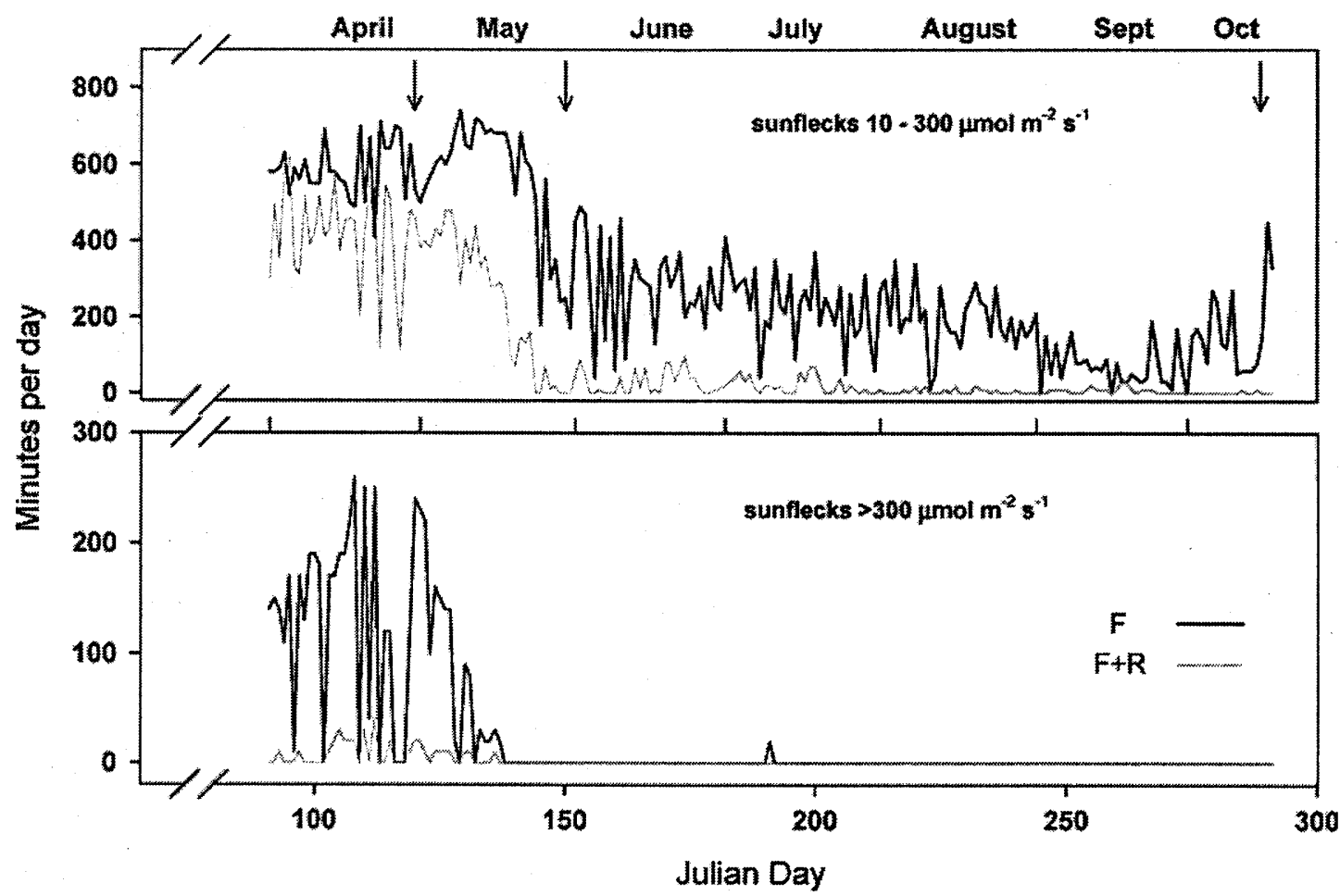

Figure 1. The daily duration of sunflecks in the range between 10 and $300 \mu \mathrm{mol} \mathrm{m}^{-2} \mathrm{~s}^{-1}$ (upper panel) and greater than $300 \mu \mathrm{mol} \mathrm{m} \mathrm{m}^{-2} \mathrm{~s}^{-1}$ (lower panel) during the growing season in 1996. Data collected using quantum sensors positioned in one forest site without a thicket of Rhododendron maximum $(\mathrm{F})$ and one adjacent site with a thicket of $R$. maximum $(\mathrm{F}+\mathrm{R})$ recording at 10 min intervals. Arrows represent the onset and conclusion of leaf out in the spring, and the onset of leaf fall in the autumn.

Table 1. Measurements using quantum sensors placed on the forest floor on 7 selected days between June 12 and August 27, 1996.

\begin{tabular}{lll}
\hline Light parameter & $\mathrm{F}$ & $\mathrm{F}+\mathrm{R}$ \\
\hline Mean PPFD $\left(\mu \mathrm{mol} \mathrm{m} \mathrm{m}^{-2} \mathrm{~s}^{-1}\right)$ & & \\
$\quad$ Overcast days & $10.3-12.0$ & $1.3-1.6$ \\
$\quad$ Clear days & $18.3-63.2$ & $2.0-10.4$ \\
$\%$ PPFD $>10 \mu \mathrm{mol} \mathrm{m}^{-2} \mathrm{~s}^{-1}$ & & \\
$\quad$ Overcast days & $67-71$ & $0-8$ \\
$\quad$ Clear days & $42-92$ & $0-8$ \\
Maximum PPFD $\left(\mu \mathrm{mol} \mathrm{m}^{-2} \cdot \mathrm{s}^{-1}\right)$ & $15.5-34.7$ & $1.9-6.9$ \\
$\quad$ Overcast days & $163.0-799.0$ & $6.7-162.0$ \\
$\quad$ Clear days &
\end{tabular}

$\mathrm{F}=$ forest sites without a thicket of Rhododendron maximum; $\mathrm{F}+\mathrm{R}=$ forest sites with a thicket of $R$. maximum. Values are 10-min averages between $1000 \mathrm{~h}$ and $1400 \mathrm{~h}$ EST.

$3_{\mathrm{F}+\mathrm{R}}$ and $\left.4_{\mathrm{F}+\mathrm{R}}\right)$. The evergreen foliage of $R$. maximum prevented light from penetrating the thickets even in winter when the canopy was leafless (Figure 2). To estimate the amount of additional shading cast by $R$. maximum, we applied suntracks the paths of the sum aerose the sky constructed from zenith and azimuth angles over the day based on a given latitude on given days of the year) for July on hemispherical photographs taken in December for $F+R$ sites (Table 2). We found thickets intercepting approximately half of the light reaching the shrub layer (i.e., $F$ sites received 34\% of PPFD as sunflecks, and in F+R sites it was only $15 \%$ ). In July, these values were reduced to $1.6 \%$ in $F$ sites and $1.3 \%$ in $\mathrm{F}+\mathrm{R}$ sites (the difference between sites was significant at $p=0.05$, ANOVA). Between December and July, the duration of daily sunflecks greater than $10 \mu \mathrm{mol} \mathrm{m}^{-2} \mathrm{~s}^{-1}$ PPFD decreased by $97 \%$ from approximately $300 \mathrm{~min} \mathrm{~d}^{-1}$ to $10 \mathrm{~min}^{-1}$ in $\mathrm{F}$ sites, and by $92 \%$ from $125 \mathrm{~min}^{-1}$ to $10 \mathrm{~min} \mathrm{~d}^{-1}$ in $\mathrm{F}+\mathrm{R}$ sites (Table 2). When the canopy was leafless, the duration of sunflecks in $F$ sites was about 3 times longer than that in $\mathrm{F}+\mathrm{R}$ sites but this difference between sites disappeared in July.

The relationship between canopy openness in $F$ and $F+P$ sites using ranked data show that in 


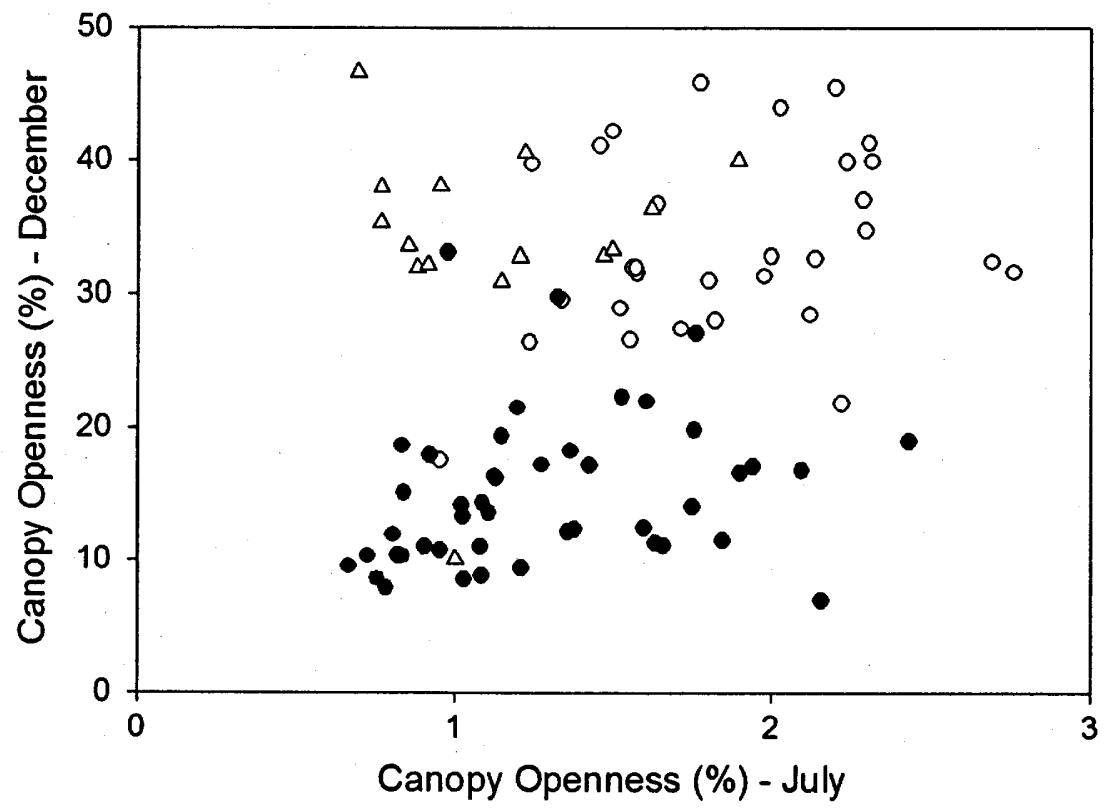

Figure 2. Canopy openness (\%) of the 90 locations in Coweeta in July and December, derived from hemispherical photographs. Due to the evergreen shrub cover, the 45 locations located in forest with a thicket of Rhododendron maximum ( $\mathrm{F}+\mathrm{R}$, solid circles). were less open in December than those located in forest sites without a thicket of $R$. maximum (F, open circles). While $F$ sites were generally more open than F+R sites in July, plots in some forest locations (open triangles) were noticeably dimmer than many $F+R$ locations.

Table 2. Direct light parameters in forest with and without a thicket of Rhododendron maximum at Coweeta. Each parameter was estimated from hemispherical photographs taken in July (+ canopy) and December (-canopy) using the same July suntrack input.

\begin{tabular}{|c|c|c|c|c|c|c|c|}
\hline & & $1_{F}$ & $2 \mathrm{~F}$ & $5_{F}$ & $3_{F+R}$ & $4_{F+R}$ & $6_{F+R}$ \\
\hline \multirow[t]{2}{*}{ Sunfleck duration (min $\mathrm{d}^{-1}$ ) } & +canopy & $12.5 \pm 2.6$ & $9.7 \pm 2.8$ & $7.5 \pm 1.9$ & $14.1 \pm 3.0$ & $9.4 \pm 2.9$ & $5.3 \pm 1.0$ \\
\hline & -canopy & $297.3 \pm 12.3$ & $331.7 \pm 14.5$ & $284.9 \pm 18.0$ & $115.0 \pm 13.0$ & $133.2 \pm 20.6$ & $126.9 \pm 9.9$ \\
\hline \multirow[t]{2}{*}{ Sunfleck PPFD $\left(\mathrm{mol} \mathrm{m}^{-2} \mathrm{~d}^{-1}\right)$} & + canopy & $0.53 \pm 0.10$ & $0.46 \pm 0.16$ & $0.22 \pm 0.08$ & $0.46 \pm 0.10$ & $0.35 \pm 0.12$ & $0.20 \pm 0.05$ \\
\hline & -canopy & $8.54 \pm 0.51$ & $11.03 \pm 0.63$ & $9.23 \pm 0.78$ & $4.26 \pm 0.46$ & $4.67 \pm 0.79$ & $4.35 \pm 0.44$ \\
\hline \multirow[t]{2}{*}{$\%$ PPFD as sunflecks } & + canopy & $2.0 \pm 0.4$ & $1.7 \pm 0.6$ & $0.9 \pm 0.3$ & $1.7 \pm 0.4$ & $1.3 \pm 0.4$ & $0.7 \pm 0.2$ \\
\hline & -canopy & $31.5 \pm 1.9$ & $40.7 \pm 2.3$ & $34.0 \pm 2.9$ & $15.7 \pm 1.7$ & $17.2 \pm 2.9$ & $16.0 \pm 1.6$ \\
\hline$\%$ light penetration & + canopy & $1.93 \pm 0.27$ & $1.81 \pm 0.44$ & $0.89 \pm 0.13$ & $1.53 \pm 0.25$ & $1.18 \pm 0.22$ & $0.87 \pm 0.16$ \\
\hline
\end{tabular}

Sunfleck parameters were derived from a single day: July 10 . The six blocks, three with $R$. maximum shrub present (subscript $\mathrm{F}+\mathrm{R}$ ) and three without (subscript F), are randomly selected within the forest approximately $500 \mathrm{~m}$ between centers of adjacent blocks. Seasonal canopy photographs were taken at 15 marked locations (plots) within each block.

December, canopy openness in $\mathrm{F}+\mathrm{R}$ sites was reduced consistently by $20 \%$ due to the evergreen foliage of the shrub layer (Figure 3). The plateau in canopy openness of $F$ sites in December indicates that woody structures alone imposed an upper limit in maximum canopy openness of ca. 47\%. Minimum values in the lower part of the December plot suggest that, even under a leafless canopy, canopy openness can be as low as 7-10\% under both forest types. Under a closed canopy (in July), the difference between the sites was much smaller with $F$ sites only marginally brighter than the $F+R$ sitze f Figure s inset

\section{Photosynthetic responses of $Q$. rubra and $P$. serotina}

To assess the effect of the prevailing light environments on regenerating tree seedlings, we first examined typical diel patterns of photosynthesis for $Q$. rubra. Measurements were determined on sunny days using randomly chosen naturally occurring seedlings within both forest types (Figure 4). As expected, seedling photosynthesis fluctuated with light intensity during the daylight hours. Average total daily carbon gain from a representative diur-

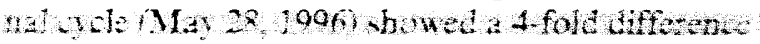




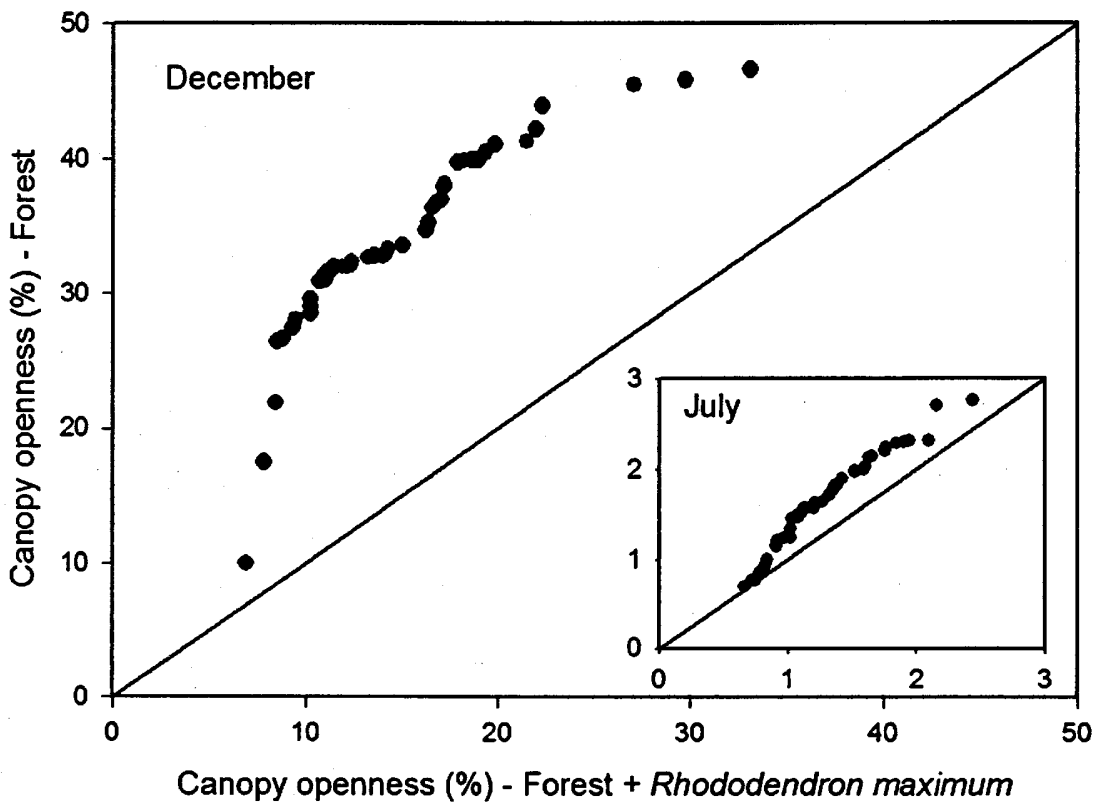

Figure 3. The distribution of canopy openness between forest sites without a thicket of Rhododendron maximum (forest) and forest sites with a thicket of $R$. maximum (forest + Rhododendron maximum) in July (inset) and December. Ranked values were used to demonstrate the effect of the $R$. maximum thicket on canopy openness when the forest canopy was open (December) and closed (July). The diagonal lines represent 1:1 relationships.

between $\mathrm{F}\left(8.38 \pm 0.49 \mathrm{mmol} \mathrm{m}^{-2}\right)$ and $\mathrm{F}+\mathrm{R}$ sites $\left(1.96 \pm 0.11 \mathrm{mmol} \mathrm{m} \mathrm{m}^{-2}\right)$. Seedling dark respiration was similar between forest types (Figure 4). The mean mid-day photosynthetic rates for all Q. rubra seedlings on all dates in 1996 measured in F sites $\left(2.1 \pm 0.1 \mu \mathrm{mol} \mathrm{m}^{-2} \mathrm{~s}^{-1}\right)$ was $62 \%$ higher than that of all seedlings located in $\mathrm{F}+\mathrm{R}$ sites $(1.3 \pm 0.1 \mu$ $\mathrm{mol} \mathrm{m} \mathrm{m}^{-2} \mathrm{~s}^{-1}$ ). Mean mid-day photosynthesis for $Q$. rubra seedlings in $\mathrm{F}+\mathrm{R}$ sites was significantly lower than that for Q. rubra seedlings in $\mathrm{F}$ sites on three out of four measurement dates in 1996 (Table 3). Mean mid-day PPFD incident upon seedlings located in F sites $\left(32.3 \pm 8.1 \mu \mathrm{mol} \mathrm{m}^{-2} \mathrm{~s}^{-1}\right)$ was $355 \%$ higher than the incident PPFD experienced by seedlings in $\mathrm{F}+\mathrm{R}$ sites $\left(7.1 \pm 1.7 \mu \mathrm{mol} \mathrm{m} \mathrm{m}^{-2} \mathrm{~s}^{-1}\right)$. These light levels are similar to those recorded by quantum sensors (Table 1). Similar to 1996, the seasonal mean mid-day photosynthetic rate for 1997 was $183 \%$ higher in $F$ sites $(1.7 \pm 0.2$ $\left.\mu \mathrm{mol} \mathrm{m} \mathrm{m}^{-2} \mathrm{~s}^{-1}\right)$ than those in $\mathrm{F}+\mathrm{R}$ sites $\left(0.6 \pm 0.1 \mu \mathrm{mol} \mathrm{m}^{-2} \mathrm{~s}^{-1}\right)$. The seasonal mean PPFD experienced by $Q$. rubra seedlings located in $\mathrm{F}$ sites during photosynthetic measurements $(100 \pm 16.9$ $\mu \mathrm{mol} \mathrm{m} \mathrm{m}^{-2} \mathrm{~s}^{-1}$ ) was $257 \%$ higher than the seasonal mean PPFD incident upon seedlings in $\mathrm{F}+\mathrm{R}$ sites $\left(28 \pm 5.1 \mu \mathrm{mol} \mathrm{m}^{-2} \mathrm{~s}^{-1}\right)$. Two-way analysis of

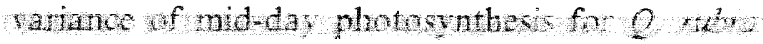

seedlings in 1997 (after natural log transformation to meet normality) found a significant effect of date, forest type and their interaction (Table 4). Therefore, mid-day photosynthesis of $Q$. rubra seedlings was significantly lower in $F+R$ sites than $F$ sites in 1997 allowing for the significant effects of date.

For $P$. serotina seedlings, the mean mid-day photosynthesis in 1997 was highest in $F$ sites $\left(0.7 \mu \mathrm{mol} \mathrm{m}^{-2} \mathrm{~s}^{-1} \pm 0.1\right)$ while plants located in $\mathrm{F}+\mathrm{R}$ sites exhibited a negative mean mid-day photosynthetic rate, $\left(-0.1 \mu \mathrm{mol} \mathrm{m}^{-2} \mathrm{~s}^{-1} \pm 0.1\right)$. Mean mid-day photosynthesis for $P$. serotina seedlings in $\mathrm{F}+\mathrm{R}$ sites was significantly lower than that for $P$. serotina seedlings in $\mathrm{F}$ sites on two out of three measurement dates in 1997 (Table 3). Seasonal mean incident PPFD experienced by $P$. serotina seedlings in $\mathrm{F}$ sites $\left(18 \pm 1.5 \mu \mathrm{mol} \mathrm{m}^{-2} \mathrm{~s}^{-1}\right)$, was $67 \%$ higher than the seasonal mean incident PPFD experienced by $P$. serotina seedlings in $F+R$ sites $(10.8 \pm 2.4$ $\mu \mathrm{mol} \mathrm{m}{ }^{-2} \mathrm{~s}^{-1}$ ).

\section{Light-dependent photosynthetic response}

To determine whether further physiological acclimatien to the deper hade under $R$ nuximam w 


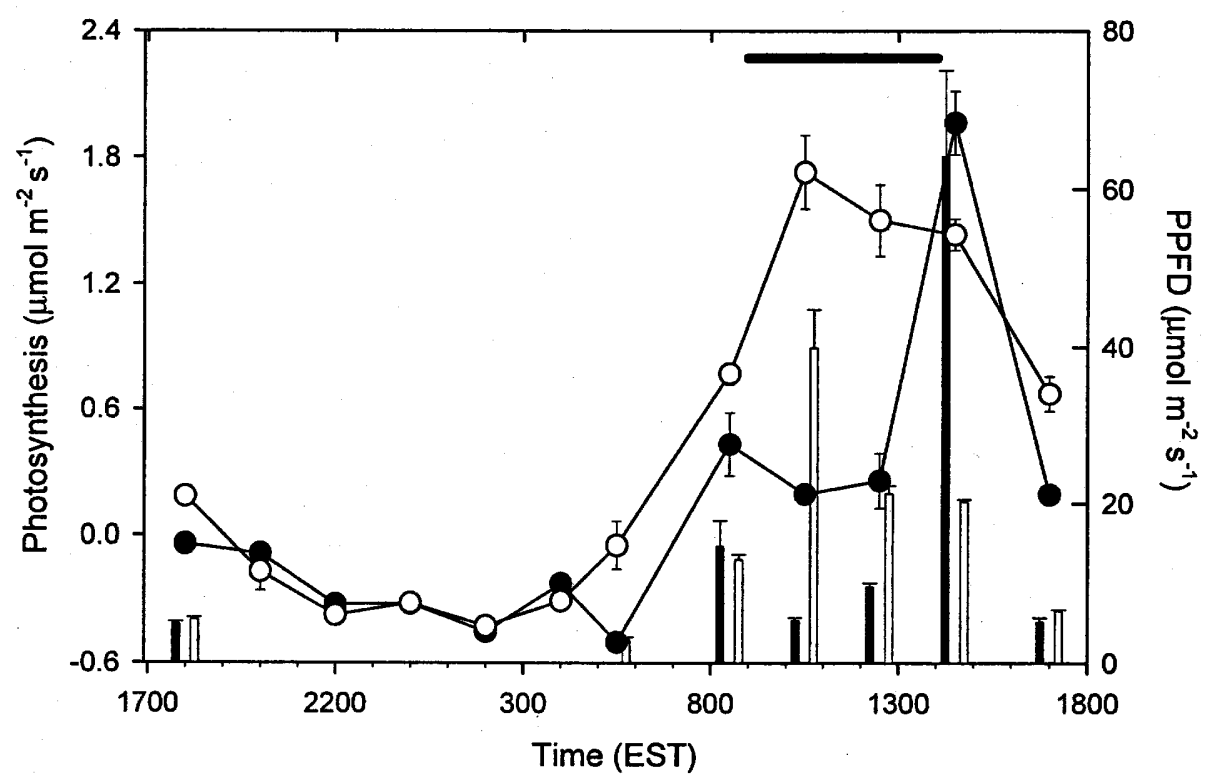

Figure 4. A representative diel $(24 \mathrm{~h})$ curve of photosynthesis (circles) for $Q$. rubra seedlings located in forest without (open symbols) and with a thicket of $R$. maximum (closed symbols) in the subcanopy. Bars represent PPFD incident upon the leaf when photosynthetic measurements were logged. Data represent mean \pm 1 standard error $(n=5$ plants). Solid line at top of graph indicates the time of day used for mid-day photosynthetic measurements.

Table 3. Mean mid-day photosynthesis ( \pm 1 standard errors of the mean) for Quercus rubra and Prunus serotina seedlings growing in forest with $(\mathrm{F}+\mathrm{R})$ or without $(\mathrm{F})$ a thicket of Rhododendron maximum in the subcanopy.

\begin{tabular}{clllr}
\hline Year & Species date & & F & \multicolumn{1}{l}{ F+R } \\
\hline 1996 & Q. rubra & May-7 & $0.90 \pm 0.068$ & $1.16 \pm 0.179$ \\
& & June-20 & $2.28 \pm 0.051^{*}$ & $1.86 \pm 0.085$ \\
& & July-21 & $2.08 \pm 0.063^{*}$ & $1.14 \pm 0.081$ \\
1997 & \multirow{2}{*}{ P. serotina } & August-22 & $3.28 \pm 0.236^{*}$ & $2.26 \pm 0.161$ \\
& & May-2 & $0.01 \pm 0.127$ & $-0.47 \pm 0.079$ \\
& & June-10 & $0.59 \pm 0.033^{*}$ & $-0.09 \pm 0.039$ \\
& Q. rubra & July-16 & $1.49 \pm 0.096^{*}$ & $-0.12 \pm 0.062$ \\
& May-10 & $1.73 \pm 0.190^{*}$ & $0.04 \pm 0.008$ \\
& & June-14 & $2.18 \pm 0.125$ & $2.27 \pm 0.227$ \\
& & July-16 & $0.48 \pm 0.045^{*}$ & $0.06 \pm 0.011$ \\
& August-21 & $2.34 \pm 0.156^{*}$ & $1.24 \pm 0.192$
\end{tabular}

Significant differences $(t$-test) are denoted by asterisk $(*), \alpha=0.05$.

measured photosynthetic responses of $Q . r u b r a$ and $P$. serotina seedlings to light and found little difference between forest types. Among the parameters derived from light response curves (Figure 5), i.e., light compensation point $\left(I_{\mathrm{c}}\right)$, apparent quantum yield $\left(\Phi_{\mathrm{I}}\right)$, light saturation point $\left(I_{\mathrm{s}}\right)$ and $A_{\max }$, only $A_{\max }$ was significantly higher $(p<0.05)$ for $Q$. rubra seedlings located in $\mathrm{F}$ sites compared with those in $F+R$ sites (Table 5). No significant effect of forest twpo on these parametens wax found in
$P$. serotina seedlings (Table 5). Characteristic of shade grown plants, the light compensation point was extremely low for both species growing in either forest type. Dark respiration rates derived from light response curves on $Q$. rubra was $0.5 \mu \mathrm{mol} \mathrm{m}^{-2} \mathrm{~s}^{-1}$, similar to the nocturnal respiration rates measured during diel cycles (Figure 4). The light compensation point of both species was between 3 and $5 \mu \mathrm{mol} \mathrm{m}^{-2} \mathrm{~s}^{-1}$ PPFD (Table 5). Comparing to the Mean PPFD reported in Table 1, assimilation by seedlings of both species in $\mathrm{F}+\mathrm{R}$ sites were below their light compensation point on overcast days and only reaching their compensation point on most clear days.

\section{Discussion}

Light level in mid-summer (July) determined by both quantum sensors and hemispherical photographs clearly indicated an overall higher cumulative PPFD in forest locations without $R$. maximum in the understorey: 15.5 (F) and $3.0 \mathrm{~mol} \mathrm{~m}^{-2}$ month $^{-1}(\mathrm{~F}+\mathrm{R}$; quantum sensors $)$; $20.7 \pm 2.9$ (F) and $9.3 \pm 1.7 \mathrm{~mol} \mathrm{~m}^{-2} \mathrm{mo}$ $\mathrm{nth}^{-1}(\mathrm{~F}+\mathrm{R}$; total site factor derived from hemi-

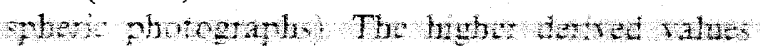


Table 4. Results from two-way analysis of variance for natural log transformed, mid-day photosynthesis of Quercus rubra seedlings growing in a southern Appalachian forest.

\begin{tabular}{llllll}
\hline Source of variation & df & SS & MS & F & P \\
\hline Date & 3 & 158.7 & 52.9 & 62.5 & $<0.0001$ \\
Forest Type & 1 & 39.3 & 39.291 & 46.4 & $<0.0001$ \\
Date $\times$ forest type & 3 & 34.3 & 11.42 & 13.5 & $<0.0001$ \\
Residuals & 161 & 136.3 & 0.847 & \\
Total & 168 & 404.7 & 2.409 & & \\
\hline
\end{tabular}

Effects evaluated were date (julian day of measurement in 1997) and forest type (forest with or without a subcanopy thicket of $R$. maximum) and their interaction. Significance of the effects was determined by Student-Newman Keuls test.

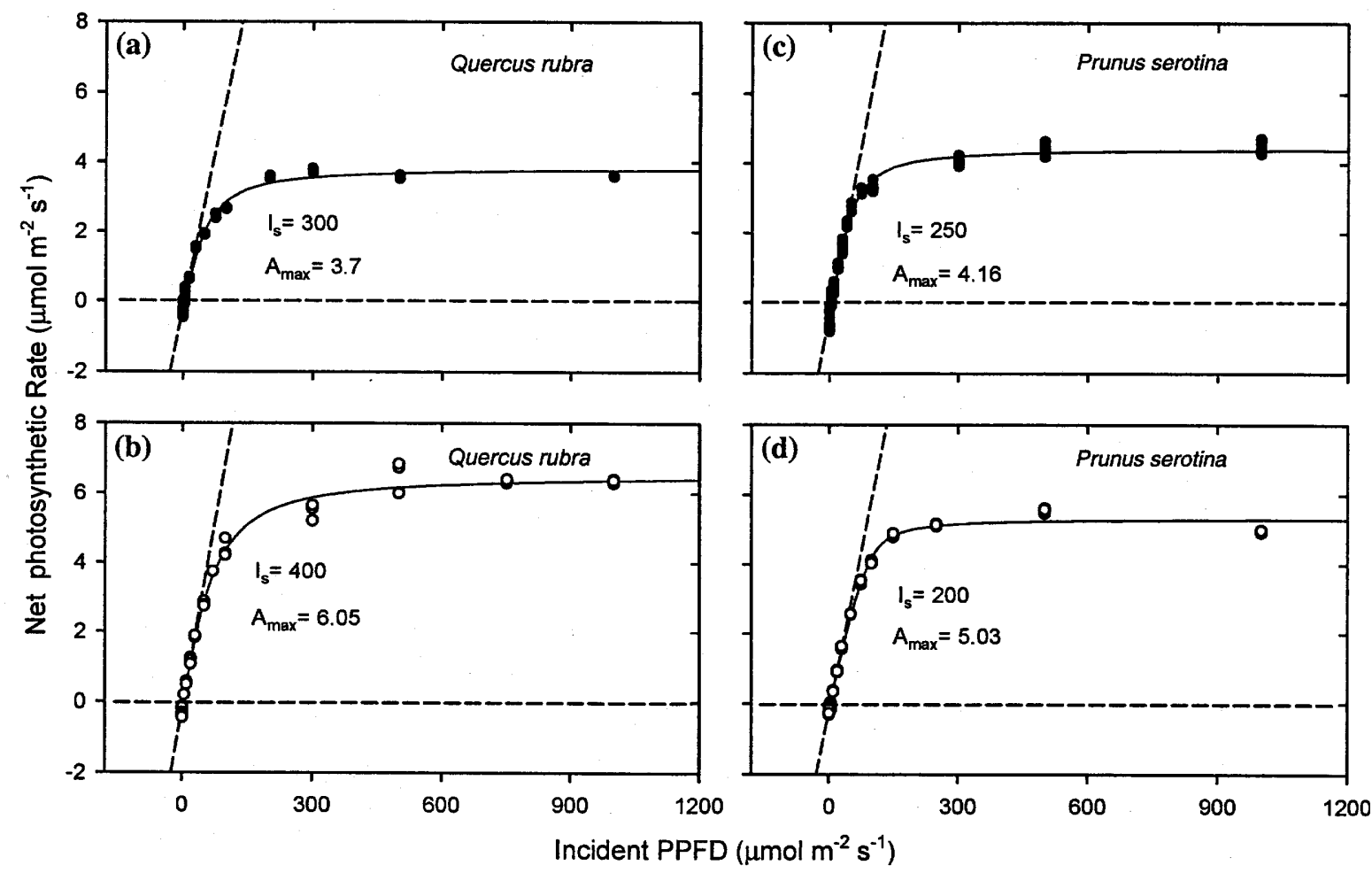

Figure 5. Representative light response curves measured during 1997 on Quercus rubra and Prunus serotina seedlings locate in forest with (closed symbols) and without (open symbols) a thicket of Rhododendron maximum in the subcanopy.

from hemispherical photographs assumed clear skies, thus, represented the potential maximum irradiance, while quantum sensor measurements were actual values including overcast days.

The percent direct light penetration in July (derived from hemispherical photographs) in the six sites ranged between 0.9 and $1.9 \%$ (Figure 2). This is similar to the $1-2 \%$ full sun Chazdon and Fetcher (1984) found in a tropical forest understorey. Clark et al. (1993) also found late successional species regenerating in a tropical forest understory at $19-2.4 \%$ direct light The averace
PPFD of $12 \mu \mathrm{mol} \mathrm{m}^{-2} \mathrm{~s}^{-1}$ and $0.5 \mathrm{~mol} \mathrm{~m}^{-2} \mathrm{~d}^{-1}$ under an intact rain forest understorey (Chazdon and Fetcher 1984) are also comparable to our study where $F$ sites had values marginally higher than $F+R$ sites (Tables 1 and 2). These results suggest that the light environment under $R$. maximum thickets in the southern Appalachian forest is generally dimmer compared to the understorey of an intact rain forest.

Canopy openness estimated for December (Figure 3) indicated that even without canopy leaves at least half of the $\mathrm{k} \mathrm{k}$ was obscured by tb: 
Table 5. Derived parameters from all light response curves generated during 1997 on both Quercus rubra and Prunus serotina seedlings.

\begin{tabular}{lcccc}
\hline Species parameter & \multicolumn{2}{l}{ Q. rubra } & & \multicolumn{2}{l}{ P. serotina } \\
\cline { 2 - 5 } & $\mathrm{F}$ & $\mathrm{F}+\mathrm{R}$ & $\mathrm{F}$ & $\mathrm{F}+\mathrm{R}$ \\
\hline Apparent quantum yield $\left(\Phi_{1}\right)$ & $0.06 \pm 0.006$ & $0.05 \pm 0.006$ & $0.05 \pm 0.004$ & $0.06 \pm 0.004$ \\
Light compensation point $\left(I_{\mathrm{c}}\right)$ & $2.8 \pm 0.3$ & $5.2 \pm 1.3$ & $5.2 \pm 1.21$ & $4.6 \pm 0.85$ \\
Light saturation point $\left(I_{\mathrm{s}}\right)$ & $400 \pm 68.1$ & $360 \pm 53.6$ & $192 \pm 23.9$ & $211 \pm 24.3$ \\
Light saturated rate $\left(A_{\max }\right)$ & $5.2 \pm 0.35^{*}$ & $3.5 \pm 0.25$ & $3.0 \pm 0.54$ & $3.7 \pm 0.38$ \\
\hline
\end{tabular}

Significant differences in means between forest with a thicket of Rhododendron maximum $(F+R)$ in the subcanopy and forest without a thicket of $R$. maximum $(\mathrm{F})$ in the subcanopy. Significant differences $\left(t\right.$-test) are denoted by asterisk $\left({ }^{*}\right), \alpha=0.05$. Units: Apparent quantum yield $=\mu \mathrm{mol} \mathrm{CO}_{2}$ assimilated $/ \mu \mathrm{mol}$ photons absorbed; Light compensation point $=\mu \mathrm{mol} \mathrm{m}^{-2} \mathrm{~s}^{-1}$; Light saturation point $=\mu \mathrm{mol} \mathrm{m}^{-2} \mathrm{~s}^{-1}$; Light saturated rate $=\mu \mathrm{mol} \mathrm{CO}_{2} \mathrm{~m}^{-2} \mathrm{~s}^{-1}$. Mean values were based on $6-10$ measurements.

woody tissue of canopy trees even in F sites. Also, if we assume a similar amount of woody tissue in the canopy above $R$. maximum thickets, then the evergreen foliage of $R$. maximum will intercept an additional $2 / 3$ of the light passing through the forest canopy. The actual quantum sensor data from July, however, indicates a much smaller difference in available light between $F$ and $F+R$ sites, which we attribute partly to the higher abundance of deciduous understorey saplings of the forest without $R$. maximum thickets (F sites) than forest with a thicket of $R$. maximum (Lei, personal observation).

\section{Availability of sunflecks}

The growth and survival of shade-adapted late successional species depends more on sunflecks than the same amount of light at low diffused levels over longer periods (Watling et al. 1997). This observation highlights the critical importance of the difference in sunfleck duration in the $10-$ $300 \mu \mathrm{mol} \mathrm{m}^{-2} \mathrm{~s}^{-1}$ range between $\mathrm{F}$ and $\mathrm{F}+\mathrm{R}$ sites. During the months of June-August, the total duration of sunflecks of this intensity range in $F$ sites was about $4 \mathrm{~h}$ per day, but it was only $18 \mathrm{~min}$ in $F+R$ sites. Furthermore, plants growing in $F+R$ sites received 0 min of sunflecks on $45 \%$ of the days during June-August (Figure 1). Analysis of light response curves in seedlings indicated that light saturation of photosynthesis occurred at approximately $10 \%$ full sun for $P$. serotina seedlings and $20 \%$ full sun for $Q$. rubra seedlings (Figure 5). Given the rarity of these light levels at Coweeta the observed differences in intensitv and duration of sunflecks between $F$ and $F+R$ sites could mean the difference between having some seedlings persisting in the $F$ sites and none in $F+R$ sites. Since the presence of seedlings and saplings resident (advance regeneration) are critical to forest regeneration associated with episodic disturbance events (Bazzaz 1979; Canham 1985, 1989, 1990), this could lead to different patterns of regeneration between forest sites with and without a understorey of $R$. maximum.

\section{Availability of diffuse light}

The availability of diffuse light, in conjunction with the high rates of precipitation $\left(2000 \mathrm{~mm} \mathrm{yr}^{-1}\right)$ in Coweeta, would have a significant impact on the carbon budget of regenerating seedlings and their survival. Diffuse light greater than $4 \mathrm{~mol} \mathrm{~m}^{-2}$ month $^{-1}$ in July at the 90 plots was detected in $44 \%$ (63\% if excluding the usually $\operatorname{dim} 5_{\mathrm{F}}$ ) of F site plots and only $20 \%$ of the $F+R$ site plots. Quantum sensor data showed PPFD in F+R sites falling below the LCP of 3-5 $\mu \mathrm{mol} \mathrm{m} \mathrm{m}^{-2} \mathrm{~s}^{-1}$ on overcast days and was only marginally above the LCP on clear days (Tables 1 and 3). These LCP values are very similar to the $5 \mu \mathrm{mol} \mathrm{m}^{-2} \mathrm{~s}^{-1}$ of two Japanese Quercus species grown under $2 \%$ full sun (Takenaka 1986).

\section{Carbon gain of regenerating tree seedlings}

In 1996, virtually all measured $\mathrm{CO}_{2}$ assimilation rates of $O$, ruhra seedlings at mid-day were positive 
( $>92 \%$ for both $\mathrm{F}$ and $\mathrm{F}+\mathrm{R}$ sites) and, in 1997, only $69 \%$ of the measured $\mathrm{CO}_{2}$ assimilation rates were positive in $\mathrm{F}+\mathrm{R}$ sites versus $99 \%$ in $\mathrm{F}$ sites. Prunus serotina seedlings maintained positive photosynthesis less frequently in general, i.e., $77 \%$ in $\mathrm{F}$ sites and $62 \%$ in $\mathrm{F}+\mathrm{R}$ sites in 1997. Therefore, it is clear that seedlings of both species had a greater chance of experiencing irradiance near or below the light compensation point for photosynthesis in $F+R$ sites than in $F$ sites. Consistent with the observed carbon gain at these light levels, mortality of $P$. serotina seedlings in Coweeta ( $>90 \%$ ) was much greater than Q. rubra $(50 \%$, Lei et al. 2002) over 2 years. While our findings of the greater shade tolerance of $Q$. rubra over $P$. serotina agree with Farrar (1995), Canham et al. (1994) found higher sapling mortality over 5 years in $Q$. rubra (81\%) than P. serotina (31\%). Perhaps the discrepancy arose from an ontogenetic difference in shade tolerance between seedlings and saplings of the two species. Also, our data indicate that two-year old $Q$. rubra seedlings are likely to have lower photosynthetic rates than one-year old $Q$. rubra seedlings and suggest an increased risk of mortality in older seedlings. These data provide clear evidence that light limitation under $R$. maximum thickets inhibits carbon gain of forest tree seedlings and the inhibition becomes greater as seedlings age.

Acclimation to the deep shade under Rhododendron thickets

The greater attenuation of light under the thickets creates an environment where seedlings could acquire greater shade acclimation to enhance their survival. Typically, shade acclimated plants have lower $A_{\max }$, dark respiration rates, and $I_{\mathrm{c}}$ points as well as higher carboxylation efficiencies under lower incident PPFD; as a result, such plants are capable of withstanding longer periods of lowlight suppression in the forest understorey (Canham 1989). Thus, increased shade acclimation by $Q$. rubra and $P$. serotina seedlings could prolong survival under $R$. maximum thickets, by improving seedling chances of experiencing and capitalizing on a gap in the overstory. However, we found no evidence of photosynthetic acclimation in $Q$. rubra and $P$. serotina seedlings growing under $R$. maxinum thickets dopits inamatically different incident PPFD between F+R and F sites. Seedlings of both species exhibited similar features of shade acclimation in $\Phi_{\mathrm{I}}$, extremely low $I_{\mathrm{c}}$ points, dark respiration rates, and low $A_{\max }$ (Pfitsch and Pearcy 1989; Larcher 1995; Nilsen and Orcutt 1997). Also other studies have failed to demonstrate an effect of increased shade on photosynthetic acclimation (Midgely et al. 1992; Mitchell and Arnott 1995; Groninger et al. 1996), but none of these experiments were conducted in light environments as low as those present in the mature forests at Coweeta. The only result differentiating seedlings in $\mathrm{F}$ sites and $\mathrm{F}+\mathrm{R}$ plots is a significantly higher $A_{\max }$ in $Q$. rubra seedlings in areas without an understorey of $R$. maximum. However, this alone would not confer a greater shade tolerance to seedlings growing under a thicket of $R$. maximum.

In general, estimated direct and diffuse light factors are significantly correlated with diameter and height growth of tropical seedlings and saplings (Clark et al. 1993; Oberbauer et al. 1993). At $1 \%$ full sun, temperate forest species show significant differences in their probability of mortality during a 2.5-year period (Kobe et al. 1995). One possible reason for the higher survival rate of $Q$. rubra compared with $P$. serotina could be its earlier start of leaf expansion in the spring. Quercus rubra seedlings begin photosynthesis before canopy closure (Figure 1) and assimilation gained during the period of open canopy can represent a substantial portion of the seedlings' annual carbon gain (Walters and Reich 1996). However, under a thicket of $R$. maximum the much lower intensity and shorter duration of sunflecks (Figure 1) makes carbon gain difficult for seedlings even during this period. We believe the lower carbon gain in early spring contributed to the higher mortality of $Q$. rubra in $\mathrm{F}+\mathrm{R}$ sites compared with that in $\mathrm{F}$ sites.

Following canopy closure, $Q$. rubra seedlings require an estimated minimum of $22 \mathrm{mmol}$ $\mathrm{m}^{-2} \mathrm{~d}^{-1}$ total assimilation to prevent a daily carbon deficit (based on measured dark respiration of $0.5 \mu \mathrm{mol} \mathrm{m} \mathrm{m}^{-2} \mathrm{~s}^{-1}$ for $12 \mathrm{~h}$ ). Addition carbon gain would be required to balance respiratory losses from roots and stems. Using values derived from light-dependent photosynthesis of seedlings, the duration of assimilation required to achieve zero daily carbon balance is described in Figure 6 .

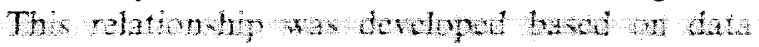




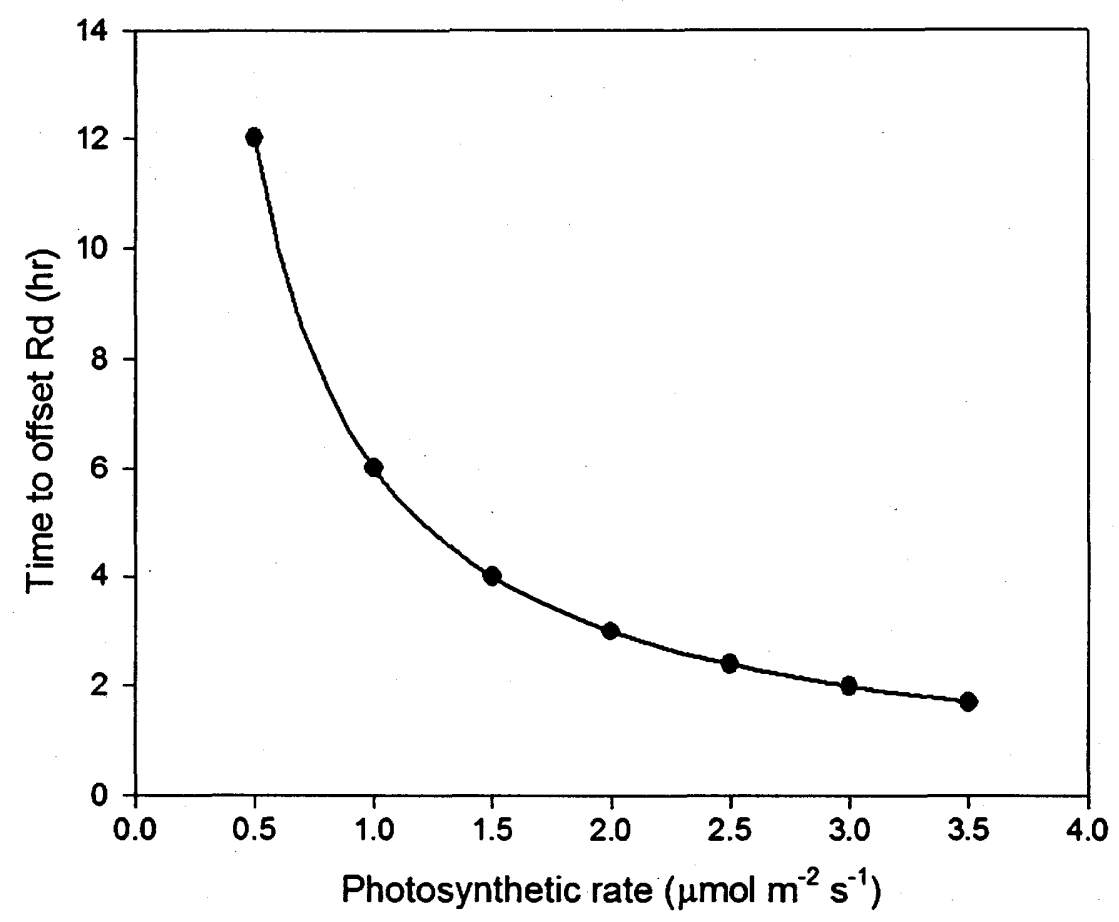

Figure 6. Assuming a dark respiration rate (Rd) of $0.5 \mu \mathrm{mol} \mathrm{m}^{-2} \mathrm{~s}^{-1}$ and a duration of $12 \mathrm{~h}$ darkness daily, this plot shows the time required per day at realistic rates of photosynthesis for Quercus rubra seedlings to counterbalance carbon loss by leaves through nocturnal dark respiration. Data points are photosynthetic rates at $0.5 \mu \mathrm{mol} \mathrm{m} \mathrm{m}^{-2} \mathrm{~s}^{-1}$ intervals. Note that field measurements indicate maximum photosynthesis for $Q$. rubra was about $3.5 \mu \mathrm{mol} \mathrm{m}^{-2} \mathrm{~s}^{-1}$ attained at ca. $380 \mu \mathrm{mol} \mathrm{m} \mathrm{m}^{-2} \mathrm{~s}^{-1}$ PPFD.

collected for the month of July when both available light and seedling physiological activities would be at or nearing their seasonal maximum. According to Figure 6, a positive carbon balance is possible if a seedling can maintain photosynthetic rates of $1.0 \mu \mathrm{mol} \mathrm{m} \mathrm{m}^{-2} \mathrm{~s}^{-1}$ or higher for $6 \mathrm{~h}$ or longer in a day. To achieve this rate a mean PPFD of $30 \mu \mathrm{mol} \mathrm{m}^{-2} \mathrm{~s}^{-1}$ or a total site factor of $>20 \mathrm{~mol} \mathrm{~m}^{-2}$ month $^{-1}$ (or ca. $0.7 \mathrm{~mol} \mathrm{~m}^{-2} \mathrm{~d}^{-1}$ ) is necessary. Among the 90 plots, only 12 in the $\mathrm{F}$ sites and 8 in the $F+R$ sites provided this amount of light in July. While it is not possible to predict seasonal carbon gain from these calculations, it is clear that most of the sites examined in Coweeta (and proportionally more locations in $\mathrm{F}+\mathrm{R}$ sites than in F sites) had insufficient amount of light to maintain carbon gain in oak seedlings. An understorey herb Adenocaulon bicolor can assimilate $17 \mathrm{mmol} \mathrm{m} \mathrm{m}^{-2} \mathrm{~d}^{-1}$ of carbon at a total PPFD of $0.4 \mathrm{~mol} \mathrm{~m}^{-2} \mathrm{~d}^{-1}$ (Pearcy and Pfisch 1993). In comparison, we found a much lower daily carbon gain of $Q$. rubra in May between $2(\mathrm{~F}+\mathrm{R})$ and 8 mmol $\mathrm{m}^{-2} \mathrm{~d}^{-1}$ (F) We infer from thest ressits that seedlings in Coweeta likely experienced daily carbon deficit regularly during the growing season.

\section{Conclusions}

Based on the distribution of light in time and space in the Coweeta forest, we attribute the lack of seedlings under $R$. maximum thickets to three factors. One, seedlings growing under the thickets regularly encountered light levels insufficient to maintain a net daily carbon gain. Two, the evergreen cover of $R$. maximum does not permit substantial carbon gain by seedlings during the month prior to canopy closure. Three, tree seedlings were unable to achieve increased shade acclimation under the dimmer $R$. maximum cover, resulting in greater carbon deficit. Our data showed that most tree seedlings will not persist for more than 23 years in the shade of the thickets (Lei et al. 2002).

But, just as there was no clear dichotomy in ambient light between gap and intact canopy (Srith at il 1002 i some of oy $F$ i $R$ sites expe 
rienced light levels comparable to most $\mathrm{F}$ sites. Seedlings in these brighter $F+R$ locations should persist for longer periods of time. However, the absence of older tree seedlings in these brighter patches under $R$. maximum thickets implicates other contributing factors, such as below-ground competition and interference with mycorrhizal association (Walker et al. 1999; Nilsen et al. 2001), are further restricting tree seedling survival under the thickets. Given the persistence of $R$. maximum in the Coweeta forest, it could have an enduring effect on regenerating tree seedlings and, consequently, on the forest landscape of the region.

\section{Acknowledgements}

This study was funded by USDA Forest/Range/ Crop/Wetland Ecosystems Program, Grant \# 9537101-1902. Logistical assistance was provided by USDA Forest Service, Coweeta Hydrologic Laboratory. The use of a fisheye lens was kindly provided by Y. Maruyama. Canopy photo images were analyzed using FEW 4.0, a PC-based software developed by M. Ishizuka of Forestry and Forest Products Research Institute, Tsukuba, Japan.

\section{References}

Anderson M.C. 1964. Studies of the woodland light environment. I. The photographic computation of light conditions. J. Ecol. 52: 27-41.

Bazzaz F.A. 1979. The physiological ecology of plant succession. Annu. Rev. Ecol. Syst. 10: 351-372.

Beier C.M., Horton J.L., Walker J.F., Clinton B.D. and Nilsen E.T. 2005. Carbon limitation leads to suppression of first year oak seedling beneath evergreen understory shrubs in Southern Appalachian hardwood forests. Plant Ecol. 176: 131-142.

Canham C.D. 1985. Suppression and release during canopy recruitment in Acer saccharum. Bull. Torrey Bot. Club 112: 134-145.

Canham C.D. 1989. Differences responses to gaps among shade tolerant tree species. Ecology 70: 560-562.

Canham C.D. 1990. Suppression and release during canopy recruitment in Fagus grandifolia. Bull. Torrey Bot. Club 117: $1-7$.

Canham C.D., Finzi A.C., Pacala S.W. and Burbank D.H. 1994. Causes and consequences of resource heterogeneity in forests: interspecific variation in light transmission by canopy trees. Can. J. For. Res. 24: 337-349.

Chazdon R.L. 1988. Sunflecks and their importance to forest understorey plants. Adv. Ecol. Res. 18: 1-63.
Chazdon R.L. and Fetcher N. 1984. Photosynthetic light environment $I-a$ lowland tropical rain forest in Costal Rica. J. Ecol. 72: 553-564.

Chazdon R.L. and Field C.B. 1987. Photographic estimation of photosynthetically active radiation: evaluation of a computerized technique. Oecologia 73: 525-532.

Clark D.B., Clark D.A. and Rich P.M. 1993. Comparative analysis of microhabitat utilization by saplings of nine tree species in a neotropical rain forest. Biotropica 25: 397-401.

Constabel A.J. and Lieffers V.J. 1996. Seasonal patterns of light transmission through boreal mixedwood canopies. Can. J. For. Res. 26: 1008-1014.

Cross J.R. 1981. The establishment of Rhododendron ponticum in the Killarney oakwoods, S.W. Ireland. J. Ecol. 69: 807-824.

Day F.P. Jr., Phillips D.L. and Monk C.D. 1988. Forest communities and patterns. In: Swank W.T. and Crossley D.A. (eds.), Forest Hydrology and Ecology at Coweeta, Springer, Berlin, pp. 141-150.

Dobbs M.M. 1995. Spatial and temporal distribution of the evergreen understorey in the southern Appalachians. University of Georgia, Athens, GA. MS thesis.

Easter M.J. and Spies T.A. 1994. Using hemispherical photography for estimating photosynthetic photon flux density under canopies and in gaps in Douglas-fir forests of the $\mathrm{Pa}$ cific Northwest. Can. J. For. Res. 24: 2050-2058.

Ellsworth D.S. and Reich P.B. 1992. Water relations and gas exchange of Acer saccharum seedlings in contrasting natural light and water regimes. Tree Physiol. 10: 1-20.

Farrar J.L. 1995. Trees in Canada. Canadian Forest Service, Ottawa.

Fladeland M.M., Ashton M.S. and Lee X. 2003. Landscape variations in understory PAR for a mixed deciduous forest in New England, USA. Agric. For. Meterol. 118: 137-141.

Gates D.M. 1980. Biophysical Ecology. Springer-Verlag, Berlin. Groninger J.W., Seiler J.R., Peterson J.A. and Kreh R.E. 1996. Growth and photosynthetic responses of four Virginia Piedmont tree species to shade. Tree Physiol. 16: 773-778.

Jennings S.B., Brown N.D. and Sheil D. 1999. Assessing forest canopies and understorey illumination: canopy closure, canopy cover and other measures. Forestry 72: 59-73.

Johnson J.D., Tognetti R., Michelozzi M., Pinzauti S., Minotta G. and Borghetti M. 1997. Ecophysiological responses of Fagus sylvatica seedlings to changing light conditions. II. The interactions of light environment and soil fertility on seedling physiology. Physiol. Plantarum 101: 124-134.

Jones R.H. and McLeod K.W. 1990. Growth and photosynthetic responses to a range of light environments in Chinese tallowtree and Carolina ash seedlings. For. Sci. 36: 851-862.

Kobe R.K., Pacala S.W. and Silander J.A. Jr. 1995. Juvenile tree survivorship as a component of shade tolerance. Ecol. Appl. 5: 517-532.

Larcher W. 1995. Physiological Plant Ecology. Springer, Berlin.

Lei T.T. and Koike T. 1998. Functional leaf phenotypes for shaded and open environments of a dominant dwarf bamboo (Sasa senanensis) in northern Japan. Int. J. Plant Sci. 159: $812-820$

Lei T.T., Semones S.W., Walker J.F., Clinton B.D. and Nilsen E.T. 2002. Effects of Rhododendron maximum thickets on tree seed dispersal, seedling morphology, and survivorship. Int. J. Plant Sci. 163: 991-1000. 
Lipscomb M.V. and Nilsen E.T. 1990. Environmental and physiological factors influencing the natural distribution of evergreen and deciduous ericaceous shrubs on northeast and southwest slopes of the southern Appalachian mountains I Irradiance tolerance. Am. J. Bot. 77: 108-115.

Machado J.-L. and Reich P.B. 1999. Evaluation of several measures of canopy openness as predictors of photosynthetic photon flux density in deeply shaded conifer-dominated forest understory. Can. J. For. Res. 29: 1438-1444.

Midgley G.F., Rutherford M.C., Davis G.W. and de Bosenberg J.W. 1992. Photosynthetic response of heliophilous Rhus species to environmental modification by invasive shrubs. Funct. Ecol. 6: 334-345.

Mitchell A.K. and Arnott J.T. 1995. Effects of shade on the morphology and physiology of amabilis fir and western hemlock seedlings. New For. 10: 79-98.

Mitchell P.L. and Whitmore T.C. 1993. Use of hemispherical photographs in forest ecology. O.F.I. Occasional papers No. 44. Oxford Forestry Institute.

Monk C.D. and Day F.P. Jr. 1985. Vegetation analysis, primary production and selected nutrient budgets for a southern Appalachian oak forest: a synthesis of IBP studies at Coweeta. For. Ecol. Manage. 10: 87-113.

Nilsen E.T. and Orcutt D.M. 1997. Physiology of Plants Under Stress: Abiotic Factors. John Wiley and Sons, New York.

Nilsen E.T., Walker J.F., Miller O.K., Semones S.W., Lei T.T. and Clinton B.D. 1999. Inhibition of seedling survival under Rhododendron maximum (Ericaceae): could allelopathy be a cause?. Am. J. Bot. 6: 1957-1605.

Nilsen E.T., Clinton B.D., Lei T.T., Miller O.K., Semones S.W. and Walker J.F. 2001. Does Rhododendron maximum L. (Ericaceae) reduce the availability of resources above and belowground for canopy tree seedlings?. Am. Midl. Nat. 145: $325-343$.

Oberbauer S.F., Clark D.B., Clark D.A., Rich P.M. and Vega G. 1993. Light environment, gas exchange, and annual growth of saplings of three species of rain forest trees of Costa Rica. J. Trop. Ecol. 9: 511-523.

Pearcy R.W. and Pfisch W.A. 1993. The consequences of sunflecks for photosynthesis and growth of forest understory plants. In: Schulze E.-D. and Caldwell M.M. (eds.), Ecophysiology of Photosynthesis, Springer-Verlag, Berlin, pp. 343-359.
Pfitsch W.A. and Pearcy R.W. 1989. Steady-state and dynamic photosynthetic response of Adenocaulon bicolor (Asteraceae) in its redwood forest habitat. Oecologia 80: $471-476$.

Rich P.M. 1989. A Manual for Analysis of Hemispherical Canopy Photography. Manual LA-11733-M, Los Alamos National Laboratory, Los Alamos, NM.

Rich P.M. 1990. Characterizing plant canopies with hemispherical photographs. Remote Sensing Rev. 5: 13-29.

Rich P.M., Clark D.B., Clark D.A. and Oberbauer S.F. 1993. Long-term study of solar radiation regimes in a tropical wet forest using quantum sensors and hemispherical photographs. Agric. For. Meteorol. 65: 107-127.

Roxburgh J.R. and Kelly D. 1995. Uses and limitations of hemispherical photography for estimating forest light environments. New Zeal. J. Ecol. 19: 213-217.

Smith A.P., Hogan K.P, and Idol J.R. 1992. Spatial and temporal patterns of light and canopy structure in a lowland tropical moist forest. Biotropica 24: 503-511.

Swank W.T. and Crossley D.A. Jr. (eds), 1988. Forest Hydrology and Ecology at Coweeta. Springer-Verlag, New York.

Takenaka A. 1986. Comparative ecophysiology of two representative Quercus species appearing in different stages of succession. Ecol. Res. 1: 129-140.

Turner I.M. 1990. Tree seedling growth and survival in a Malaysian rain forest. Biotropica 22: 146-154.

Walker J.F., Lei T.T., Semones S.W., Nilsen E.T., Clinton B.D. and Miller O.K. 1999. Suppression of ectomycorrhizae on canopy tree seedlings in Rhododendron maximum L. (Ericaceae) thickets in the southern Appalachian mountains. Mycorrhizae 9: 49-56.

Walters M.B. and Reich P.B. 1996. Are shade tolerance, survival and growth linked? Low light and nitrogen effects on hardwood seedlings. Ecology 77: 841-853.

Watling J.R., Ball M.C. and Woodrow I.E. 1997. The utilization of lightflecks for growth in four Australian rain-forest species. Funct. Ecol. 11: 231 -239.

Whitmore T.C., Brown N.D., Swaine M.D., Kennedy D., Goodwin-Bailey C.I. and Gong W.-K. 1993. Use of hemispherical photographs in forest ecology: measurement of gap size and radiation totals in a Bornean tropical rain forest. J. Trop. Ecol. 9: 131-151. 